\title{
The Analysis of Causes of Business Financial Distress
}

\author{
Lucia Michalkova $^{\mathrm{a} *}$, Peter Adamko ${ }^{\mathrm{b}}$, Maria Kovacova ${ }^{\mathrm{c}}$ \\ Faculty of Operation and Economics of Transport and Communications \\ University of Zilina \\ Zilina, the Slovak Republic \\ lucia.michalkova@fpedas.uniza.sk ${ }^{\mathrm{a} *}$ \\ peter.adamko@fpedas.uniza.sk ${ }^{b}$ \\ maria.kovacova@fpedas.uniza.sk ${ }^{\mathrm{c}}$
}

\begin{abstract}
Economic growth is one of the most striking phenomena of recent years. The global economy is considered to be powerful and powerful. Nevertheless, signs of the deteriorating financial condition of the state, the population and surrounding businesses must be perceived. Financial management of any company should not neglect examining the causes of financial distress from a microeconomic and macroeconomic perspective. At the same time, businesses do not look at these causes as separate events, but perceive their interconnectedness. The aim of this paper is therefore to detect, investigate and summarize the causes of corporate failure.
\end{abstract}

Keywords-Deterioration of financial health; Bankrupcy; Prediction model; Corporate failure

\section{INTRODUCTION}

The 2009 financial crisis has brought failures and subsequent bankruptcy to many businesses not excluding investment bank Lehman Brothers. Both the lay public and many economists consider this moment as the beginning of one of the biggest crises of since the Great Depression in the 1930s. However, the Lehman Brothers bankruptcy must be considered as a consequence or a symptom of the crisis and not its cause. The causes of the financial crisis can be a policy of cheap money (low interest rates, cheap mortgage loans) that is linked to the unbearable debt of the state, the population as well as the enterprises [1-3].

Businesses should reflect changes in macroeconomic indicators, the state's economic situation and global economic trends. Adequate evaluation of these phenomena can provide the company sufficient time and financial reserves to overcome the global crisis [4.5]. On the other hand, the immediate vicinity of the business should not be neglected either. The causes of the crisis may not be macroeconomic in nature; on the contrary, they may be based on a lack of financial management, bad relations with business partners, and so on.

The aim of this paper is therefore to detect, investigate and summarize the causes of corporate failure.

\section{CAUSES OF BUSINESSES FINANCIAL HEALTH DETERIORATION}

In general, the term "financial distress" is used in a negative connotation to describe the financial health of an enterprise that is confronted with a temporary liquidity shortage and with difficulties resulting in a failure to meet financial obligations within their payment terms and to their full extent. There are currently a few hundreds, perhaps up to thousands of prediction models that have been developed at a specific time and under the conditions of specific economies [6-8]. The basic question that their authors had to ask is: when can we consider the business "financially sound" and when it is on the way to failure or bankruptcy. In order to be able to answer this question with justification, we should first know the causes of the failure. A wide range of causes exists, we will list some of them. I.I. Mitroff [9] discovers eight basic causes of financial health deterioration:

- Economic causes - strikes, labor riots, market failure, a decline in core earnings and sharp changes in market prices.

- Information causes - incorrect information, loss of protected and confidential information, machinations with computer data processing, loss of sensitive data related to customers, suppliers and other stakeholders.

- Physical causes - loss, destruction or damage to important assets - raw materials, machinery and equipment, means of transport.

- Human resources - departure, loss of key experts or managers, lack of skilled workforce in the labor market.

- Reputation - defamation, spreading false or alarming news about the company, damaging the good name of the business, theft of intellectual property, imitation of business logo.

- Causes of criminal nature - hostile takeover, terrorism, violence at the workplace.

- Natural disasters - earthquakes, fires, floods, hurricanes, whirlwinds, volcano eruptions, etc.

Slatter \& Lovett [10] divide the causes of business financial health deterioration into endogenous and exogenous ones, and they explore these causes further in detail. They further state that exogenous factors can only affect companies in a minimal way but the company cannot be separated from the current dynamically evolving environment.

1. Endogenous causes

- weak management and its mistakes,

- insufficient financial control,

- poor management of working capital, 
- high expenses,

- insufficient marketing,

- undertaking projects which are too large for the company,

- excessive production volume compared to the structure of financing,

- negative impacts of mergers and acquisitions,

- inappropriate financial policy of the company,

- incorrect and ambiguous in-house policies that lead to the lack of commitment and confusion between employees during their fulfillment.

2. Exogenous causes

- negative changes in market demand for the company's products,

- competition,

- change in input commodity prices in an unfavorable direction.

On the basis of general economic theory Lizal [11] defines three causes or models that can detect the deterioration of the company financial health:

- The neoclassical model, in which case bankruptcy is considered a positive event because it allows the release of assets that have not been allocated efficiently. In this case, the market has basically a healing effect as inefficient businesses also consume inputs, which is not desirable from the economic point of view because the assets were allocated for inappropriate business activities.

- The financial model which works with the idea that the assets are correctly allocated, but that the structure of asset covering resources was inadequately set, i.e., weighted average cost of capital (WACC) is not minimal. In other words, the capital structure is not optimal.

- The corporate governance model which is based on the premise that both the assets and the liabilities of the company described in the previous two models are used efficiently, but there is poor management of the company, therefore, the bankruptcy is the result of ineffective problem management.

Altman and Hotchkiss [12] mention other causes of deterioration in the financial health of enterprises, which most of the businesses cannot influence, these are, therefore, external factors:

- chronically problematic sectors of economy (e.g. agriculture, textile industry, etc.)

- deregulation of key sectors (e.g. airlines, financial services, healthcare, energy);

- high real interest rates,

- international competition,

- excessive capacity between sectors.

New technology as the next cause of companies failure is defined by Norton [13] as an environmental factor that destroys demand for old products or services. He also mentions government policies in this area as the cause of the deterioration of business financial health. However, he adds that under the same circumstances, some businesses will survive while others will be failing. Authors Charan and Useem [14] claim that the main causes of business failure are:

- acts of God,

- managerial errors,

- relaxation (blessing) because of achieved success,

- behavior of competitors,

- underestimation of negative messages and trends,

- acceptance of excessively high risk.

Another important issue that needs to be taken into account when assessing the financial health of companies is the relationship between the age of the firm and the possibility of failure. Dun and Bradstreet, inc. [15] in its research showed that more than $50 \%$ of all failures occurred in enterprises "aged" from two to five years. After five years of existence businesses tend to be more stable and experienced, indirect consequences of that is a better access to capital, whether in the form of a loan or through issuing shares or bonds. Other, especially financial reasons for corporate failure, are as follows:

- Industry sectors - some industries tend to be chronically "unhealthy". Businesses operating in these sectors have a high probability of failure in the near future,

- Interest rates - As a result of high interest rates, some businesses will find themselves in a situation where they can no longer repay their obligations to the bank, whether in the form of interest or principal repayments.

- Competition - international division of labour and competition enormously increases business spending.

- Debts to equity ratio - Businesses, especially in the United States, have increased the volume of foreign resources. The financial leverage has increased, but businesses have become more vulnerable. This fact is particularly important in the economic recession.

- Deregulation - deregulation of key sectors leads to a competitive environment, which reduces the value of monopolistic rent.

- Growth rate - high speed of creating new businesses will cause higher business failure rates. New businesses are characterized by a higher probability of failure than established businesses, as was stated in the introduction to this paragraph.

The causes of financial problems of enterprises are dealt with by G. W. Newton [16] who bases his work on both the Dun and Bradstreet study, he lists causes of business failure as follows:

- inability to manage cash flow,

- starting a business with a low level of equity,

- absence of a good business plan,

- setting of unreal, inadequate goals,

- excessive optimism

- underestimation of the company's weaknesses,

- insufficient marketing, 
- inexperienced management,

- underestimation of competition,

- organizational arteriosclerosis,

- inadequate or incorrect delegation of decision making powers,

- hiring inappropriate managers,

- excessive dependence on one customer.

According to Brigham and Gapenski [17], the causes of financial difficulties are usually the result of a series of mistakes, bad judgment and the interdependent weaknesses of a particular business or its management which can be assigned directly or indirectly to management, and the signs of potential financial stress are generally evident before the enterprise actually fails.

Arnold [18] described some of the reasons for the deterioration of business financial health that affect the risk of incurring the costs of financial stress. This description is from the emergence of financial stress costs point of view. He mentions that the causes or factors vary and are specific for each individual enterprise:

- Increased sensitivity of business revenues to macroeconomic situation. If corporate fundamentals are sensitive to the volatility of the economy, shareholders and creditors may perceive a greater risk of financial stress and, therefore, require higher returns as a substitution for undergoing this high risk in comparison to enterprises that are less sensitive to economic events.

- Inappropriate share of fixed and variable costs. An enterprise whose activity is highly capital intensive, i.e. it works with high operating expenses, is unable to cover the need for capital by its own resources, and, therefore, increases the share of foreign capital, which can have fatal consequences.

- Lack of liquidity and tradability of company assets. Some businesses invest in types of assets that can be easily and quickly sold, they allocate their funds to assets with high liquidity. The reverse may be the cause of financial health problems in a business.

- Insufficient ability of the company to keep sufficient cash. Some businesses generate regular and sufficient cash-flow; on the other hand, companies with delayed and insufficient cash receipts may have problems in the future.

And finally, we list the reasons for the deterioration of the business financial health according to the Czech authors Synek et. al. [19], who emphasize the impact of the external environment due to the fact that the external environment is not influenced by the business itself:

- political,

- economic,

- financial,

- monetary,

- legal and tax factors,

- social factor,

- factors resulting from the nature of the industry.
Zopounidis \& Dimitras [20] recognize two groups of bad business management decisions that may be the potential causes of financial health deterioration, which they further classify internally as:

1. Financial and investment causes:

- Inappropriate ratio of company's own and borrowed resources - Inappropriate dependence on borrowed resources in most cases results in higher profits, but also increases the risk of financial stress.

- Insufficient creation of financial reserves - despite internal rationality, business owners in the period of economic growth prefer higher profits and, therefore, the company gets a long-term exposure to the risk of financial stress.

- Excessively long accounts receivable payment collection terms.

- Undercapitalization of a business - a situation where the golden balance rule is not complied with, in a sense that long-term assets are covered only in part by long-term liabilities. The remainder is covered by short-term liabilities.

- Flexibility in cost reduction - represents one of the necessary prerequisites or steps for preventing company failure. In particular, reducing fixed and wage costs is problematic.

- Ignorance about company's own capital costs - some businesses, especially in the economic conditions of transition countries, often behave as if the type of capital they borrowed were for free but the opposite is true.

- Incorrect price calculation - as a result of this the fair sale price is determined unfairly.

2. Non-financial Causes:

- lack of business strategy or bad strategy and mismanagement.

- lack of knowledge and incorrect approach of the management.

- reluctance and fear to take vigorous actions.

- insufficient competitiveness of company products.

- inappropriately chosen product portfolio and bad marketing campaign.

- Low labor productivity.

- Late recognition of first signs of enterprise failure.

- Wrong reaction or no reaction to the symptoms of corporate failure.

\section{CONCLUSION}

The deterioration of the company's financial health is the result of many macroeconomic and microeconomic causes. For some of these reasons, most businesses have a negligible impact (GDP growth, unemployment or monetary policy); other causes are intrinsic in character and the enterprise can not only introduce measures to alleviate them but also to eliminate them altogether $[21,22]$.

Current economic trends indicate economic growth and a strong global economy. Nevertheless, the possible causes of the 
future economic crisis, such as quantitative easing, the gradual rise of extremely low interest rates, and the increasing indebtedness of states and businesses appear. In addition to these, there are other qualitative phenomena (causes) that cannot be included in standard prediction models $[23,24]$. The question is whether businesses are able to correctly evaluate these causes, include them in the financial health predictions, and apply appropriate countermeasures.

\section{ACKNOWLEDGMENT}

The paper is an output of the science project VEGA 1/0428/17 Creation of new paradigms of financial management at the threshold of the 21 st century in conditions of the Slovak Republic.

\section{REFERENCES}

[1] T. Kliestik, M. Misankova, K. Valaskova, and L. Svabova, "Bankruptcy prevention: new effort to reflect on legal and social changes," Science and Engineering Ethics, vol. 24(2), pp. 791-803, 2018.

[2] M. Radisic and D. Dobromirov, "Statistical analysis of price returns of regional stock market indices," Transformations in Business \& Economics, vol. 16, no. 3 (42), pp. 175-184, 2017.

[3] Y.Z. Alshehhi and J. Olah, "Sectorial analysis: Growth accounting of secondary industries," Network Intelligence Studies, vol. 5(9), pp. 39-45 2017.

[4] E. Nica and C. Mirica (Dumitrescu), "Are Increasing Student Loan Debt Levels Burdening Graduates?" Journal of Self-Governance and Management Economics, vol. 5(2), pp. 68-74, 2017.

[5] H.J. Holzer, "Building a New Middle Class in the Knowledge Economy," Psychosociological Issues in Human Resource Management, vol. 5(2), pp. 96-126, 2017.

[6] T. Kliestik and J. Majerova, "Selected issues of selection of significant variables in the prediction models," .Proceedings of 10th international scientific conference: Financial management of firms and financial institutions, part II, pp. 537-543, 2015.

[7] A.P. Balcerzak, T. Kliestik, D. Streimikiene, and L. Smrcka, "NonParametric Approach to Measuring the Efficiency of Banking Sectors in European Union Countries," Acta Polytechnica Hungarica, vol. 14(7), pp. 51-70, 2017.
[8] Z. Wroblowska, "Requirements for Brand Managers and Product Managers Responsible for Competitiveness of Product and Brands," Journal of competitiveness, vol. 8(3), pp. 5-21, 2016.

[9] I.I. Mitroff, Managing crises before they happen: what every executive needs to know about crisis management, New York: Amacom, 2001

[10] S. Slatter and D. Lovett, "Corporate Tournaround: Managing in Distress," Middlesex: Penguin Books, London, 1999.

[11] L. Lizal, "Determinant sof Finanicial Distress: What Drives Bankruptcy in a Transition Economy?", Working paper number 451, 2002.

[12] E.I. Altman and E. Hotchkiss, Corporate Financial Distress and Bankruptcy, 3rd ed, New Jersey: Willey Publishing, 2006.

[13] E.C.Norton, "Long-term care," in Handbook of Health Economics, vol. 1, part B, A. J. Culyer and J. P. Newhouse, Eds.Amsterdam: Elsevier, 2000, pp. 955-994.

[14] R. Charan and J. Useem, Why companies fail. Fortune, May 27, pp. 3644, 2002.

[15] Dun and Bradstreet, inc., Dun \& Bradstreet reference book of corporate managements, New York : Dun \& Bradstreet, Inc., 1980.

[16] G.W. Newton, Bankruptcy and Insolvency Accounting, Volume 1: Practice and Procedure, 7th ed., New Jersey: Wiley Publishing, 2009.

[17] E. Brigham and L. Gapenski, Financial Management, Dallas: The Dryden Press, 1996.

[18] G. Arnold, G., Corporate financial management. 5th ed. Harlow: Pearson Higher Education Limited, 2013.

[19] M. Synek, J, Dvoracek, J. Dvorak, E. Kislingerova, and G. Tomek., Managerial Economics [Manažerská ekonomika] 4th ed., Praha : Grada Publishing, 2007.

[20] C. Zopoudinis and A.I. Dimitras, Multicriteria Decision Aid Methods for the Prediction of Business Failure, Dordrecht: Kluwer Academic Publishers, 1998.

[21] M. Fronczek, "Main world exporters of goods in years 1995-2011 analysis by value added," Ekonomicko-manazerske spektrum, vol. 11(1), pp. 87-97, 2017.

[22] I. Shpolianska, A. Dolzhenko, and S. Glushenko, "Fuzzy models of web services selection in the development of service-oriented information systems for small and medium enterprises," Ekonomicko-manazerske spektrum, vol. 11(2), pp. 64-75, 2017.

[23] E. Stonkute, J. Vveinhardt, and W. Sroka, "Training the CSR Sensitive Mind-Set: The Integration of CSR into the Training of Business Administration Professionals," Sustainability, vol. 10, no. 3 (754), 2018 available at: https://www.mdpi.com/2071-1050/10/3/754.

[24] S.J. Silverman and B. Lewis, "Families in US Immigration Detention: What Does It Mean to Do 'the Right Thing'?" Contemporary Readings in Law and Social Justice, vol. 9(2), pp. 95-115, 2017. 